\title{
Effect of Marital Status on Completeness of Antenatal Care Visits among Childbearing Age Women in Rural Indonesia
}

\author{
Ratna Dwi Wulandari ${ }^{1}$, Agung Dwi Laksono², Zainul Khaqiqi Nantabah² \\ ${ }^{I}$ Faculty of Public Health, Universitas Airlangga Surabaya, Indonesia.Campus C Mulyosari Surabaya, Indonesia, \\ ${ }^{2}$ Researcher at National Institute of Health Research and Development, The Ministry of Health, The Republic of \\ Indonesia. Jl. Percetakan Negara 29, Jakarta, Indonesia.
}

\begin{abstract}
Marital status has a special meaning for pregnant women in Indonesia. A woman who is pregnant without a husband is a disgrace. The purpose of this study was to analyze the effect of marital status on completeness of antenatal care (ANC) visits among childbearing age women in rural Indonesia. The research utilizes the 2017 Indonesian Demographic and Health Survey (IDHS) data. The unit of analysis for women aged 1549 years old in rural Indonesia. The sample size of 7,783 women. The dependent variable was ANC visits. The independent variable was marital status, education level, parity, wealth status and health insurance. Analysis using Binary Logistic Regression for the final test. The results of the analysis found that married women have 1.834 times higher probability than no spouse women to make complete ANC visits. While women living with partners found no significant differences with no spouse women. Married women have a better chance of making complete ANC visits than no spouse women and women living with partners. Other variables that also affect the completeness of ANC visits are age, parity, wealth status and health insurance. It could be concluded that marital status influences the completeness of ANC visits among childbearing age women in rural Indonesia.
\end{abstract}

Keywords: Marital status, antenatal care, maternal health, rural.

\section{Introduction}

The main causes of death of pregnant women in Indonesia in 2017 are hypertension in pregnancy and postpartum hemorrhage. According to the Directorate General of Health Service, these two causes should be minimized if Antenatal Care (ANC) quality standards can be maintained properly ${ }^{1}$.

Previous research found that the low ANC visit in Indonesia is influenced by the level of knowledge of

\section{Corresponding Author:}

Ratna Dwi Wulandari

Faculty of Public Health, Universitas Airlangga

Surabaya, Indonesia.Campus C Mulyosari Surabaya,

Indonesia

e-mail: ratna-d-w@fkm.unair.ac.id pregnant women about the benefits of ANC visits. The study revealed that more pregnant women were negative. Apart from the low level of knowledge, it is also likely due to the lack of husband support. On the other hand, it was revealed the attitude of the midwife who was deemed unfriendly during the ANC visit ${ }^{2}$. Community perspectives are known to influence people's access to health services ${ }^{3}$. Another study found that the distance factor of a pregnant woman's residence to the ANC also influenced the motivation of the pregnant woman to visit. Great distances make mothers think twice about visiting $\mathrm{ANC}^{4}$. Long distances and expensive service costs are known to be one of the barriers tothe public access to health services ${ }^{5,6}$.

The maternal mortality rate (MMR) is an indicator of the quality of life of women. Indonesia has succeeded in reducing MMR from 390 to 334 per 100,000 live births in 1997. Then experienced success again in 2007 reducing MMR to 228 per 100,000 live births ${ }^{7}$. MMR 
in Indonesia experienced a fairly high increase in 2015. According to the 2015 Intercensal Population Survey (SUPAS) to 305 per 100,000 live births. This position is high among countries in ASEAN. Indonesia is lower than the MMR achieved by Laos, while compared to other ASEAN members, Indonesia is still the highest ${ }^{8}$.

Early marriage may be one of the factors triggering the high MMR in Indonesia. In 2018, around 1.2 million women will marry at the age of fewer than 18 years. Nationally, the percentage trend of women aged 20-24 years whose age at first marriage is less than 18 in 2018 has increased. Note this figure when compared with 2015-2017. When compared between rural and urban areas, early marriage is more common in rural areas 9 . The phenomenon of early marriage in Indonesia is also supported by cultural practices by ethnic groups in Indonesia ${ }^{10-12}$.

Based on the background, this study was conducted to analyze the effect of marital status on completeness of ANC visits among childbearing age women in rural Indonesia. The results of the analysis in this study help policymakers to minimize the impact of marital status on the completeness of the ANC.

\section{Materials and Method}

Data Source: The study utilizes the 2017 Indonesian Demographic Data Survey (IDHS) data. The unit of analysis was women aged 15-49 years old who had given birth in the last 5 years in rural Indonesia. Taking the 2017 IDHS sample using stratification and multistage random sampling method, to obtain a sample size of 7,783 women.

Procedure: The 2017 IDHS has obtained ethical clearance from the National Ethics Committee. The respondents' identities have all been deleted from the dataset. Respondents have provided written approval for their involvement in the study. The author has obtained permission to use the data for this study through the website: https://dhsprogram.com/data/new-userregistration.cfm.

Data Analysis: The Ministry of Health of the Republic of Indonesia recommends that the ANC during pregnancy be done at least 4 times, namely in the first trimester 1 time, in the second trimester 1 time and in the third trimester 2 times. Based on this information, ANC visits are divided into 2 categories, namely incomplete ANC visits $(<4$ times) and complete ANC visits $(\geq 4$ times) $)^{13}$.

Marital status was divided into 3 categories, namely no spouse, married and living with partners. Other independent variables were age, education level, parity, wealth status and health insurance. Education level consists of 4 categories, namely no education, primary, secondary and higher. Parity consists of 3 categories, namely primiparous $(<2)$, multiparous $(2-4)$ and grande multiparous $(>4)$. Wealth status consists of 5 categories, namely the poorest, poorer, middle, richer and richest. Health insurance consists of 2 categories, namely not having health insurance and having health insurance.

At the initial stage, the Chi-square test was used for categorical variables and the T-test for continuous variables (age). Because of the nature of the dependent variable, Binary Logistic Regression was used for the final test to determine disparity. SPSS 22 software was used for all stages of statistical analysis.

Findings: Table 1 shows the cross-tabulation between marital status and other related variables. Based on ANC visits, all marital status categories are dominated by women of childbearing age who have complete ANC visits ( $\geq 4$ times). By age, married women have a slightly older average age.

Table 1. Descriptive statistic of marital status and related variables $(n=7,783)$

\begin{tabular}{|c|c|c|c|c|c|c|c|}
\hline \multirow{3}{*}{ Variables } & \multicolumn{6}{|c|}{ Marital Status } & \multirow{3}{*}{$\mathbf{P}$} \\
\hline & \multicolumn{2}{|c|}{ No Spouse } & \multicolumn{2}{|c|}{ Married } & \multicolumn{2}{|c|}{ Living with Partner } & \\
\hline & $\mathrm{n}$ & $\%$ & $\mathrm{n}$ & $\%$ & $\mathrm{n}$ & $\%$ & \\
\hline ANC visits & & & & & & & $* * *<0.001$ \\
\hline - $\quad<4$ (ref.) & 66 & $25.5 \%$ & 1086 & $14.8 \%$ & 41 & $23.6 \%$ & \\
\hline - $\geq 4$ & 193 & $74.5 \%$ & 6264 & $85.2 \%$ & 133 & $76.4 \%$ & \\
\hline
\end{tabular}




\begin{tabular}{|c|c|c|c|c|c|c|c|}
\hline \multirow{3}{*}{ Variables } & \multicolumn{6}{|c|}{ Marital Status } & \multirow{3}{*}{$\mathbf{P}$} \\
\hline & \multicolumn{2}{|c|}{ No Spouse } & \multicolumn{2}{|c|}{ Married } & \multicolumn{2}{|c|}{ Living with Partner } & \\
\hline & n & $\%$ & n & $\%$ & $\mathbf{n}$ & $\%$ & \\
\hline Age (mean) & 259 & 28.58 & 7350 & 30.71 & 174 & 26.44 & $* * *<0.001$ \\
\hline Education Level & & & & & & & 0.121 \\
\hline - No education & 7 & $2.7 \%$ & 156 & $2.1 \%$ & 9 & $5.2 \%$ & \\
\hline - Primary & 80 & $30.9 \%$ & 2449 & $33.3 \%$ & 53 & $30.5 \%$ & \\
\hline - Secondary & 142 & $54.8 \%$ & 3778 & $51.4 \%$ & 93 & $53.4 \%$ & \\
\hline - Higher & 30 & $11.6 \%$ & 967 & $13.2 \%$ & 19 & $10.9 \%$ & \\
\hline Parity & & & & & & & $* * *<0.001$ \\
\hline - Primiparous & 126 & $48.6 \%$ & 2141 & $29.1 \%$ & 89 & $51.1 \%$ & \\
\hline - Multiparous & 114 & $44.0 \%$ & 4476 & $60.9 \%$ & 78 & $44.8 \%$ & \\
\hline - Grande multiparous & 19 & $7.3 \%$ & 733 & $10.0 \%$ & 7 & $4.0 \%$ & \\
\hline Wealth status & & & & & & & $* * *<0.001$ \\
\hline - Poorest & 143 & $55.2 \%$ & 3086 & $42.0 \%$ & 156 & $89.7 \%$ & \\
\hline - Poorer & 50 & $19.3 \%$ & 1775 & $24.1 \%$ & 11 & $6.3 \%$ & \\
\hline - Midle & 40 & $15.4 \%$ & 1236 & $16.8 \%$ & 6 & $3.4 \%$ & \\
\hline - Richer & 17 & $6.6 \%$ & 819 & $11.1 \%$ & 1 & $0.6 \%$ & \\
\hline - Richest & 9 & $3.5 \%$ & 434 & $5.9 \%$ & 0 & $0.0 \%$ & \\
\hline Health insurance & & & & & & & $* * 0.002$ \\
\hline - No & 129 & $49.8 \%$ & 3025 & $41.2 \%$ & 87 & $50.0 \%$ & \\
\hline - $\mathrm{Yes}$ & 130 & $50.2 \%$ & 4325 & $58.8 \%$ & 87 & $50.0 \%$ & \\
\hline
\end{tabular}

Note: ${ }^{*} \mathrm{p}<0.05 ;{ }^{* *} \mathrm{p}<0.01 ; * * * \mathrm{p}<0.001$.

Based on education level, all marital status categories are dominated by women with secondary education. Based on parity, no spouse women and women living with partners are dominated by primiparous women, while married women are dominated by multiparous women.

Table 1 shows that based on wealth status, all marital status categories are dominated by women who have wealth status in the poorest category. Based on health insurance ownership, all marital status categories are dominated by women who have health insurance.

Table 2 is the result of the binary logistic regression test. Table 2 informs that married women are 1.834 times more likely than no spouse women to make complete ANC visits (OR 1.834; 95\% CI 1.360-2.474). While women living with partners found no significant differences with no spouse women.

Table 2. Result of Binary Logistic Regression of Completeness of Antenatal Care Visits among Childbearing Age Women in Rural Indonesia(n=7,783)

\begin{tabular}{|l|c|c|c|c|}
\hline \multirow{2}{*}{ Predictor } & \multicolumn{4}{|c|}{$\geq \mathbf{4}$ ANC visits } \\
\cline { 2 - 5 } & $\mathbf{P}$ & OR & Lower Bound & Upper Bound \\
\hline Marital status: No spouse & - & - & - & - \\
\hline Marital status: Married & $* * *<0.001$ & 1.834 & 1.360 & 2.474 \\
\hline Marital status: Living with partner & 0.082 & 1.505 & .950 & 2.385 \\
\hline
\end{tabular}




\begin{tabular}{|l|c|c|c|c|}
\hline \multirow{2}{*}{ Predictor } & \multicolumn{4}{|c|}{$\geq$ 4 ANC visits } \\
\cline { 2 - 5 } & $\mathbf{P}$ & OR & Lower Bound & Upper Bound \\
\hline Age & $* * *<0.001$ & 1.030 & 1.018 & - \\
\hline Parity: Primiparous & - & - & -043 \\
\hline Parity: Multiparous & $* * *<0.001$ & 0.685 & 0.575 & 0.815 \\
\hline Parity: Grande multiparous & $* * *<0.001$ & 0.238 & 0.181 & 0.313 \\
\hline Wealth status: Poorest & - & - & - & - \\
\hline Wealth status: Poorer & $* * *<0.001$ & 2.073 & 1.754 & 2.451 \\
\hline Wealth status: Midle & $* * *<0.001$ & 2.607 & 2.113 & 3.217 \\
\hline Wealth status: Richer & $* * *<0.001$ & 3.283 & 2.480 & 4.346 \\
\hline Wealth status: Richest & $* * *<0.001$ & 4.510 & 2.932 & 6.937 \\
\hline Health insurance: No & & $*$ & - & - \\
\hline Health insurance: Yes & $* *<0.001$ & 1.464 & 1.286 & 1.666 \\
\hline
\end{tabular}

Note: ${ }^{*} \mathrm{p}<0.05 ;{ }^{* *} \mathrm{p}<0.01 ; * * * \mathrm{p}<0.001$.

In the Indonesian context, women who become pregnant without a partner are disgrace ${ }^{14}$. Women who are pregnant outside of marriage do not dare to go out and socialize with the community. This condition encourages not to make ANC visits. So it can be understood if the utilization of ANC is low.

Table 2 shows that age is one of the determinants of complete ANC visits. Table 2 informs that multiparous women are 0.685 times more likely than primiparous women to make complete ANC visits (OR 0.685; 95\% CI 0.575-0.815). Grande multiparous women are 0.238 times more likely than primiparous women to make complete ANC visits (OR 0.238; 95\% CI 0.181-0.313). This information shows that the higher the parity, the lower the possibility of making complete ANC visits. The effect of parity on the completeness of ANC visits was also found in several previous studies in China, Afghanistan, Guatemala, India, Kenya, Pakistan and Zambia $^{15-17}$.

Table 2 shows that women with wealth status in the poorer category are 2.073 times more likely than the poorest women to have complete ANC visits (OR $2.073 ; 95 \%$ CI 1.754-2.451). Women with wealth status in the middle category are 2.607 times more likely than the poorest women to have complete ANC visits (OR 2.1134-3.217). Women with wealth status in the richer category were 3.283 times more likely than the poorest women to have complete ANC visits (OR 3.283; 95\% CI 2.480-4.346). The richest women were 4,510 times more likely than the poorest women to have complete ANC visits (OR 4.510; 95\% CI 2.932-6.937). This information shows that the better the wealth status, the higher the possibility of making complete ANC visits. This finding confirms the positive influence of wealth status on the utilization of health services found in previous studies ${ }^{18-20}$. Poverty is one of the strong barriers to public access to utilize health service facilities ${ }^{21,22}$.

Table 2 informs that women who have health insurance are 1.464 times more likely than women who do not have insurance to make complete ANC visits (OR 1.464; 95\% CI 1.286-1.666). This information shows that having health insurance is a supporting factor for a complete ANC visit. Information on the results of this study is consistent with the objectives of the National Health Insurance (NHI), which was initiated by the government since 2014. The NHI is intended to increase public access to health care facilities ${ }^{23}$. The results of the analysis of this study indicate that NHI is on the right path.

\section{Conclusions}

Based on the results of the study it could be concluded that marital status influences the completeness of ANC among childbearing age women in rural Indonesia. Married women have a better chance of making complete ANC visits than no spouse women. Other variables that also affect the completeness of ANC visits were age, parity, wealth status and health insurance. 
Acknowledgments: The author would like to thank the ICF International, who has agreed to allow the 2017 IDHS data to be analyzed in this article.

\section{Source of Funding: Self-funding}

Conflict of Interests: The authors declared no potential conflicts of interest concerning the research, authorship, and/or publication of this article.

\section{References}

1. Directorate General of Health Services. The 2018 Directorate General of Health Services Performance Accountability Report [Internet]. Jakarta; 2019. Available from: http://yankes. kemkes.go.id/app/lakip2/downloads/2017/KP/ ditjen/lakip_ditjen_2017.pdf

2. Fitrayeni, Suryati, Faranti RM. Causes of Low Completeness of Antenatal Care Visits of Pregnant Women in the Work Area of Pegambiran Health Center (Penyebab Rendahnya Kelengkapan Kunjungan Antenatal Care Ibu Hamil Di Wilayah Kerja Puskesmas Pegambiran). J Kesehat Masy Andalas. 2015;10(1):101-7.

3. Megatsari H, Laksono AD, Ridlo IA, Yoto $\mathrm{M}$, Azizah AN. Community Perspective about Health Services Access. Bull Heal Syst Res. 2018;21:247253.

4. Rachmawati AI, Puspitasari RD, Cania E. Factors That Affect Pregnant Women Antenatal Care Visits (Faktor-faktor yang Memengaruhi Kunjungan Antenatal Care Ibu Hamil). Majority. 2017;7(1):726.

5. Laksono AD, Wulandari RD, Soedirham O. Regional Disparities of Health Center Utilization in Rural Indonesia. Malaysian J Public Heal Med. 2019;19(1).

6. Laksono AD, Wulandari RD. Urban-Rural Disparities of Facility-Based Childbirth in Indonesia. In: 4th International Symposium on Health Research (ISHR 2019). Denpasar: Atlantis Press; 2020. p. 33-9.

7. Saputra W. Maternal Mortality Rate Soars, Indonesia Retreats 15 Years (Angka Kematian Ibu Melonjak, Indonesia Mundur 15 Tahun). Jakarta; 2013.

8. Widyaningtyas T. Red Report Card on the Death Rate of Indonesian Mothers (Rapor Merah Angka Kematian Ibu Indonesia) [Internet]. Jakarta;
2018. Available from: https://katadata.co.id/ analisisdata/2018/05/30/rapor-merah-angkakematian-ibu-indonesia

9. Badan Pusat Statistik, Kementerian PPN/Bappenas. Prevention of Child Marriage, Acceleration which cannot be postponed (Pencegahan Perkawinan Anak, Percepatan yang Tidak Bisa Ditunda). Jakarta; 2020.

10. Imanugraha, S. H, Budisuari MA. Aiming for Bella Ends Early Marriage (Mengincar Si Bella Berujung Pernikahan Dini). Surabaya: Unesa University Press; 2016.

11. Hennifebriawatia, Wulanangrainia, Yanuarti R, Yandrizal, Padila, Andrikusumawijaya, et al. Determinant fakctors of early marriage in Bengkulu Tengah. Pakistan J Med Heal Sci. 2019;13(1):2025.

12. Harianja AJ. Early Marriage Rates in Indonesia Are Still High (Angka Pernikahan Dini di Indonesia Masih Tinggi) [Internet]. 2019 [cited 2020 Feb 4]. p. 1. Available from: https://www.idntimes. com/news/indonesia/axel-harianja/bkkbn-angkapernikahan-dini-di-indonesia-masih-tinggi/full

13. Laksono AD, Rukmini R, Wulandari RD. Regional disparities in antenatal care utilization in Indonesia. PLoS One. 2020;15(2):e0224006.

14. Dedi D. Marriage of Pregnant Women Because of Adultery: Descriptive Study of Islamic Law on KHI Article 53 and Ulama Opinion (Perkawinan Wanita Hamil Karena Zina: Studi Deskriptif Hukum Islam terhadap KHI Pasal 53 dan Pendapat Ulama). AlAfkar, J Islam Stud. 2019;2(2):68-87.

15. You H, Yu T, Gu H, Kou Y, Xu X-P, Li X-L, et al. Factors Associated With Prescribed Antenatal Care Utilization: A Cross-Sectional Study in Eastern Rural China. Inq (United States). 2019;56.

16. Mumtaz S, Bahk J, Khang Y-H. Current status and determinants of maternal healthcare utilization in Afghanistan: Analysis from Afghanistan demographic and health survey 2015. PLoS One. 2019;14(6):Article number e0217827.

17. Tikmani SS, Ali SA, Saleem S, Bann CM, Mwenechanya M, Carlo WA, et al. Trends of antenatal care during pregnancy in low- and middle-income countries: Findings from the global network maternal and newborn health registry. Semin Perinatol. 2019;43(5):297-307.

18. Yaya S, Da F, Wang R, Tang S, Ghose B. 
Maternal healthcare insurance ownership and service utilisation in Ghana: Analysis of Ghana demographic and health survey. PLoS One. 2019;14(4):1-13.

19. Woldeamanuel BT, Gelebo KK. Statistical analysis of socioeconomic and demographic correlates of perinatal mortality in Tigray region, Ethiopia: A cross sectional study. BMC Public Health. 2019;19(1):Article number 1301.

20. Wulandari RD, Qomarrudin MB, Supriyanto $\mathrm{S}$, Laksono $\mathrm{AD}$, Qomaruddin $\mathrm{B}$, Laksono $\mathrm{AD}$. Socioeconomic Disparities in Hospital Utilization among Elderly People in Indonesia. Indian J Public Heal Res Dev. 2019;10(11):1800-4.
21. Laksono AD, Wulandari RD. The Barrier to Maternity Care in Rural Indonesia. J Public Heal From Theory to Pract. 2020; Online First.

22. Laksono AD, Nantabah ZK, Wulandari RD. Access Barriers to Health Center for Elderly in Indonesia. Bull Heal Syst Res. 2018;21(4):228-35.

23. Nasution SK, Mahendradhata Y, Trisnantoro L. Can a National Health Insurance Policy Increase Equity in the Utilization of Skilled Birth Attendants in Indonesia? A Secondary Analysis of the 2012 to 2016 National Socio-Economic Survey of Indonesia. Asia-Pacific J Public Heal. 2020;32(1):19-26. 